\title{
The Efficiency of Regulation and Self-regulation: Croatian Media's Protection of Children's Rights (2008 - 2012)
}

\author{
Lana Ciboci ${ }^{1}$ \\ Association for Communication and Media Culture (DKMK), Croatia \\ Igor Kanižaj \\ University of Zagreb, Faculty of Political Science, Study of Journalism, Croatia \\ Danijel Labaš \\ University of Zagreb, Centre for Croatian Studies, Croatia
}

\section{doi:10.5937/comman1329147C}

\begin{abstract}
Summary: No research exists about the efficiency of regulation and self-regulation in regard to the protection of children's rights in the Croatian media. Until today no analysis has been conducted on how relevant Croatian institutions monitor the implementation of media laws and by extension the provisions relating to the protection of children's rights in the media. In this paper we seek to examine complaints of citizens and institutions sent to the Croatian Journalists' Association (CJA) regarding violations of the CJA Code of Honor as well as reports by the Office of the Ombudsman for Children, the Electronic Media Council and the Croatian Media Council, regarding complaints about violations of children's rights in the media in the past five years (2008-2012). We shall not only analyze reports by the Ministry of Internal Affairs and the Office of the Attorney General of the Republic of Croatia, but also analyze and demonstrate whether these institutions have adequately, through which methods and to what extent, responded to the disregard of children's rights in the media, in line with their legal authorities.

Based upon research findings, we offer proposals for the better protection of children's rights in the media, as well as for the work of institutions that are responsible for supervising the implementation of legal codes and ethical norms. It is necessary to define the authorities and obligations of an ad hoc body, or to transfer authorities to a previously established body. In this way the gap in the regulation of print and electronic media in Croatia would be bridged. It is also of central importance that the institutions responsible for implementing on their own initiative legal and self-regulation acts, do indeed process cases of children's rights violations, in line with their authorities. Improved coordination, new educational programs for journalists and better cooperation among the relevant institutions is expected as well.
\end{abstract}

Keywords: regulation, self-regulation, Croatian media, children's rights

\footnotetext{
${ }^{1}$ lana_ciboci@yahoo.com
} 


\section{Introduction}

Three years ago, in close collaboration with the Office of the Ombudsman for Children and the Croatian Heritage Association (Matica hrvatska), together with our colleagues we conducted an extensive content analysis study. The aim of the study was to analyze main characteristics of seven Croatian daily newspapers reporting on children in 2010. The results of this study took us by surprise, particularly the fact that of 3,453 analyzed articles only $5.5 \%$ dealt with children's rights (Ciboci et al., 2011: 143). In 23.1\% of the articles the identity of the children was revealed, although it should have been kept secret (Ciboci et al., 2011: 153). In particular, we highlight the fact that $3.5 \%$ of articles that dealt with the issue of sexual offences against children revealed their identities. Jones et al. (2010) emphasize that

"child victims need to be able to trust that their privacy will be protected as much as possible by those whom they have turned to help (...) In one study, over one-half of surveyed rape victims reported that they would be 'a lot' more likely to report an attack to the police if there was a law prohibiting the news media from disclosing their name and address" (Kilpatrick et al, 1992, cited in: Jones et al., 2010: 350).

In an attempt to explain this situation, we began by researching the issue of efficiency in the regulation and self-regulation of the Croatian media. Do parents of children whose identities have been revealed in the media indeed have nowhere to turn to and can their only satisfaction be found in the warnings issued by the Croatian Journalists' Association Board of Honor to the author of the article, or to the newspaper editor who published this information?

\section{Methodology}

This article analyzes the efficiency of regulation and self-regulation mechanisms and seeks to establish what the specific aspects of the Croatian media system are, by focusing on everyday practices. In this article, we will also provide results of research (from 2008 until 2012) on activities of the institutions that have, in line with legal and honor codes, jurisdiction over this issue: Office of the Ombudsman for Children, Electronic Media Council, Croatian Media Council, Croatian Journalists' Association - Journalists' Board of Honor, 
Ministry of Internal Affairs, Office of the Attorney General of the Republic of Croatia.

Our initial hypothesis was that we would be able to prove that relevant institutions are ensuring the protection of children's rights accordingly, primarily the right to privacy, based upon filed reports and ongoing legal action against violators of children's rights in the news media. With this goal in mind and in line with the Croatian Right to Information Act, we approached the relevant institutions in writing, as legally prescribed, requesting of them to provide us with information about actions they have taken and are currently taking against violators of children's rights, as well as to inform us about actions that have been concluded. Other sources of information about ongoing actions against violators of children's rights were found on official web pages of particular institutions, since this data is publicly available. In the period from $1^{\text {st }}$ of March until $1^{\text {st }}$ of May 2013 we collected all official reports and documents, available on web pages of the institutions that were the subject of our analysis. Following this we embarked on an analysis, from which we derived conclusions and proposals for the improvement of the current situation.

\section{From regulation and self-regulation to co-regulation}

Our analysis of the efficiency of media regulation or self-regulation does not deal with regulation in terms of infrastructure, the user's approach to content or the approach used by the content source. On the contrary, it focuses on the regulation of media content (McQuail, 2010: 236), keeping in mind the best interests of the public as the end-users, since here we are researching the violation of children's rights, as prescribed by international conventions. Although there is probably hardly any broadcaster or publisher who is thrilled with the concept of regulation, one has to admit that "media regulation started its development hand in hand with guaranteeing, promoting, and protecting freedom of expression. In fact, the ultimate goal of regulating media should be to protect and deepen this fundamental right" (Puddephatt, 2011: 7).

"Media regulators are supposed to improve the overall quality of the media and some certainly play a relevant role. They are expected to raise media standards and therefore to contribute to the expansion of public and private media social responsibilities" (Sousa et al., 2013: 5). 
They also emphasize the impact that media regulation could have on democracy, while other authors (Puppis, 2009) see media diversity as a key objective of media regulation. For him, "regulating media structure is an attempt to influence media content indirectly" (Puppis, 2009: 13). Quoting Grisold (1996) and Karppinen, (2006), Puppis (2009) identifies "two different approaches to media diversity that can be distinguished: the competition or market approach, endorsing economic regulation to prevent market failure, and the interventionist or public regulation approach, involving active media policy" (Grisold, 1996: 505; Karppinen, 2006: 58, cited in Puppis, 2009: 13).

In this respect, the regulation of print-media, radio, television and the internet varies greatly, while technology has imposed entirely new standards and challenges. McQuail (2010) points out that even an analysis of public media services, for instance of those in the United States and Europe, reveals great variations in approach. Even within a European context, it would be entirely incorrect to compare Croatian experiences with those of Germany or Scandinavia, for instance. However, what is common to all of them is what Peter Lunt and Sonia Livingstone recognize as

"changes in media and communications regulation in the wider context of globalization, market harmonization (i.e. supposedly deregulation to reduce constraints on trade within states and across borders) and technological convergence (the much-hyped ability to deliver media content on a range of platforms and devices)" (Lunt and Livingstone, 2012: 3).

Research conducted in 2003 by Piermarco Aroldi "has confirmed how each of six analyzed countries in the EU has, in accordance with its own cultural sensitivity, focused attention on the contents of television communication and the educational problems connected" (Aroldi, 2004: 191).

"Implementing a balanced governance and moving toward a viable co-regulation system as promoted by the European Union, both imply the need to call on all major actors in the media environment (decision-makers, producers and broadcasters, educators and parents, not forgetting researchers) and to hold them accountable" (Frau-Meigs, 2004: 35).

Similarly, Pier Cesare Rivoltella and colleagues echo this call in the study (2006, 2012). 
As one might assume, the responsibility of self-regulation rests on the shoulders of each individual member of the media and consequently of each member of the Croatian Journalists' Association Board of Honor. "Self-regulation is a combination of standards setting out the appropriate codes of behavior for the media that are necessary to support freedom of expression, and process how these behaviours will be monitored or held to account" (Puddephatt, 2011: 12). The fundamental notion of self-regulation - i.e. "it protects the right of journalists to be independent and impartial, and to be judged for professional mistakes, not by those in power but by their colleagues. It aims at establishing minimum standards on accuracy, professional ethics, protection of privacy and other personal rights (...)" (Zlatev, 2011:18) - has proven itself ineffective, at least when it comes to the protection of children's rights, because it does not guarantee compensation to those whose rights were violated. To be sure, selfregulation is necessary and with efficient self-regulation the journalist profession does send a very clear message to the public, but when it comes to protecting the rights of children, youth and marginalized groups in society, current practices raise the issue of human rights protection in Croatia.

"Self-regulation suffers from a lack of democratic legitimation. It originates from economic players or groups with their own specific interests - interests that may contribute to or even be partly congruent with the general interest; nevertheless, these special interests do not necessarily coincide totally with the general interest" (Palzer and Scheuer, 2004: 169).

In this paper we shall provide strong arguments why, from our perspective, the existing practice of media self-regulation and regulation cannot guarantee efficient children's rights protection in the Croatian media.

\section{Legal and ethical protection of children in Croatia}

The legal protection of children ${ }^{2}$ in Croatia is well developed, at least when it comes to media reporting. The Croatian Constitution and international agreements, as well as a large number of legal acts protect the privacy, reputation and honor of children in the media.

As the supreme legal act of the Republic of Croatia, the Constitution guarantees freedom of expression and thinking, freedom of the press and other

\footnotetext{
2 According to the Convention on the Rights of the Child, children are defined as all persons under 18, except when the adult age threshold is defined beforehand by a legal act that applies to a child.
} 
forms of communication, in particular. However, this freedom is not absolute, as Article 35 of the Constitution (85/10) guarantees to all, including children, respect and legal protection of private and family life, dignity, reputation and honor.

International agreements that are an inherent part of the internal legislative structure of the Republic of Croatia and which, from a legal perspective, stand above national laws have great significance in the Croatian legal system. ${ }^{3}$

In Croatia, a wide range of legal acts protects the privacy, dignity, reputation and honor of children. For journalists, the Media Act $(59 / 04,84 / 11)$ is of utmost importance, which in Article 16 prescribes that the media are obliged to respect the privacy, dignity, reputation and honor of citizens, particularly children, youth and families regardless of gender and sexual orientation. The same Article also forbids the publication of information that could reveal the identity of children, if this jeopardizes the well being of the child. A violation of this decree is punishable by a fine of up to one million kuna (approx. 131,000 euros). In the Electronic Media Act (153/09, 84/11, 94/13) it is also stressed that the publication of information that could reveal the identity of children under 18 involved in any form of violence, regardless of whether the child is a witness, victim, perpetrator or has attempted or committed suicide, is not permitted, nor is it allowed to reveal specific information about relations within the child's family or his or her private life. Media that reveal the identity of children in the aforementioned context can be fined from 100,000 to $1,000,000$ kuna (13,000 to 131,000 euros). When it comes to public television, the privacy, dignity, reputation and honor of children and youth are protected by the Croatian Radio-Television Act (137/10, 76/12). Although a sublegal document, the Regulations for the Protection of Juveniles (60/10) prescribe that in reporting on the role of a minor involved in any form of violence, the identity of the minor shall always be protected by a blurred, altered or masked appearance and a modulated tone, so that the minor cannot be recognized. In such instances it is prohibited to reveal specific information from the child's family or personal

\footnotetext{
3 Article 141 of the Constitution of the Republic of Croatia (Official Gazette 85/10). The Convention on the Rights of the Child, which Croatia signed in 1991, is the most important legal document protecting the rights of children. With respect to the media, the Optional Protocol to the Convention on the Rights of the Child on the Sale of Children, Child Prostitution and Child Pornography is also of key importance as well as the United Nations Standard Minimum Rules for the Administration of Juvenile Justice.
} 
life, particularly in instances when revealing such information could jeopardize the well being of the child.

The Criminal Code plays a central role in the protection of children's rights. We should note that the Criminal Code from 1997 was relevant for the period investigated in this study (2008-2012). ${ }^{4}$ Apart from ensuring the confidentiality of criminal proceedings against juveniles, the Criminal Code also prescribes incarceration from six months to three years for anyone who „presents or disseminates any information about the personal or family life of a child, resulting in the ridicule of the child on the part of the child's peers or other persons, or resulting in serious mental disturbances" (Article 201 of the Amendments to the Criminal Code, 71/06). The new Criminal Code went into effect on January 1, 2013 and marked a step forward in the protection of children's rights in the media. Apart from prescribing heavy fines for criminal offenses damaging one's reputation and honor (e.g. insult, disgrace, slander), Article 178 (Criminal Code, 125/11, 144/12) also prescribes incarceration for anyone who

"presents or disseminates information about the personal or family life of a child, publishes the child's photograph or reveals the child's identity in violation of the law, which causes the child to become agitated, or results in ridicule on the part of the child's peers or other persons, or jeopardizes the well being of the child in any other way".

Anyone who commits this through print media, radio, television, the computer system or internet, at a public gathering or by any other means through which this information becomes available to a greater number of people, shall be punished by a jail sentence of up to two years, and if the act is committed by an official or by an individual on duty, such a person shall be punished by a jail sentence of up to three years (Article 178 of the Criminal Code, 125/11, 144/12). The same sentence is prescribed for persons

"who without the permission of the court publish information about the course of a legal proceeding against the child, a legal proceeding for a criminal act committed against the child or a proceeding in which the protection of rights and interests of the child is being deliberated, as well as for revealing information about any decision reached during the legal proceeding" (Article 307 of the Criminal Code, 125/11, 144/12).

\footnotetext{
4 Following amendments to the Criminal Code in the period 1997-2011.
} 
The Juvenile Courts Act and the Criminal Offenses Act protect the identity of children who are undergoing a criminal or legal proceeding for other violations (during all phases of the proceeding).

Although a self-regulating act, the Code of Honor for Croatian Journalists is also very relevant for the work of journalists, as it prescribes that they protect human rights and uphold dignity in their work, particularly of children and youth. In comparison to certain other key international documents, such as the International Federation of Journalists' Declaration of Principles on the Conduct of Journalists, the Munich Declaration of the Duties and Rights of Journalists or the UNESCO International Principles of Professional Ethics in Journalism - which do not contain any regulations on the protection of children in the media - the Code of Honor for Croatian Journalists is very protective of children's rights. ${ }^{5}$

Although Croatia has a very well developed legal foundation for protecting children in the media, it is on rare occasions that citizens opt to engage in legal proceedings, but it is also the case - as the findings of this study show - that government institutions responsible for ensuring the successful implementation of aforementioned legal regulations, rarely sanction the media for violating them.

\section{Regulatory institutions}

\section{Electronic Media Council}

The Electronic Media Council (in further text: Council) is responsible for monitoring electronic media in the Republic of Croatia. Although the Council performs systematic monitoring of electronic media, the findings of this study point to the fact that the Council most often considers cases of children's rights violations only at the initiative of others and that it rarely does this on its own initiative. Since the Council did not respond to the request of the authors of

\footnotetext{
According to the Code of Honor, the journalist cannot interview or photograph children under the age of 14 without their consent and without the presence and consent of parents or guardians. Even with their consent, the journalist cannot interview or photograph the child if this in any way jeopardizes the child's well being. The journalist must never reveal the identity of the child or minor involved in cases of sexual misconduct or any other form of violence or criminal act, regardless of whether the child is a minor, witness, victim, suspect or has been charged. The identity of the child or minor may be revealed only in exceptional circumstances, when it is in the public interest and when it does not jeopardize the well being of the child or minor, with the consent of the parents or guardians of the child or minor, or when government bodies request the child's identity to be revealed for the sake of the child's well being. The well being of the child is superior to the public interest.
} 
this text regarding access to information - although they were obliged to do so as a public authority body (even by the law) - data recorded in annual reports and published on official web pages of the Agency for Electronic Media, about the activities of the Council, was used in this study.

Table 1: Responses of the Electronic Media Council to children's rights violations in electronic media (2008 - 2012)

\begin{tabular}{|c|c|c|c|c|}
\hline Year & Warnings & Condemnations & $\begin{array}{c}\text { Legal proceed- } \\
\text { ings for viola- } \\
\text { tions }\end{array}$ & $\begin{array}{c}\text { Administrative } \\
\text { proceeding }\end{array}$ \\
\hline $\mathbf{2 0 1 2}$ & 1 & 0 & 0 & 0 \\
\hline $\mathbf{2 0 1 1}$ & 1 & 0 & 0 & 0 \\
\hline $\mathbf{2 0 1 0}$ & 1 & 2 & 1 & 1 \\
\hline $\mathbf{2 0 0 9}$ & 0 & 0 & 0 & 0 \\
\hline $\mathbf{2 0 0 8}$ & 0 & 0 & 0 & 0 \\
\hline
\end{tabular}

From 2008 until 2012 the Council responded six times to children's rights violations in the media, issuing three warnings, two condemnations and in one instance opening a legal proceeding for the violation. The greatest number of cases in which the Council responded to children's rights violations occurred in 2010, when it issued one warning, two condemnations and opened one legal proceeding for the violation (due to one of its decisions an administrative proceeding was opened against the Council, as well). ${ }^{6}$ In comparison to 2010, in 2011 and 2012 the Council issued one warning annually. ${ }^{7}$ In 2008 and 2009

\footnotetext{
${ }^{6}$ The warning was issued to HRT. That same year, following a report filed by the Ombudsman for children and as a result of continued monitoring, the Council issued two condemnations to RTL Television Croatia for revealing the identity of a minor in a news program. Because of its disagreement with the Council's decision to issue a condemnation for a television news report about a racist masked ball in one primary school in Osijek, RTL Television Croatia started an administrative proceeding against the Council.

In 2011 the warning was addressed to RTL Television for a featured report in the show Exkluziv about underage girls, whose identities were uncovered. Initiative: citizens' complaints. A report about a mother and three daughters who discuss their living conditions. The diseases that afflicted two of the daughters were mentioned and the identities of the underage girls were revealed, along with details of their private lives. Having the parents' consent does not mean that the broadcaster has no responsibility for the well being of the children. The aired report violated Article 12 (paragraph 1) of the Electronic Media Act. Source: Electronic Media Council (2011). The online newspaper Jutarnji. $h r$ was warned for revealing the identity of a child in 2012 .
} 
the Council did not respond at all to any cases of children's rights violations in the media, although this does not mean that there weren't any.

There was only one legal proceeding for violations opened by the Council in the analyzed period. Such a proceeding took place in 2010 at the initiative of the Ombudsman for Children for a children's rights violation case in the media. It was opened against Nova TV because of an interview that aired in the show Red Carpet, in which one actress revealed a row of information about the underage daughter of her husband. The legal proceeding concluded in 2012 with a non-binding judgement and was won by the Agency for Electronic Media, with Nova $T V$ being forced to pay a high fine.

\section{Ministry of Internal Affairs of the Republic of Croatia}

From 2008 until 2012 the Ministry of Internal Affairs of the Republic of Croatia conducted four criminal investigations for suspicions of violations of rights to privacy, dignity, reputation and honor of children in the media. ${ }^{8}$ These investigations were conducted by only two police offices: the Bjelovar-Bilogora County Police Office and the Šibenik-Knin County Police Office. All four cases dealt with articles published in print media.

The Bjelovar-Bilogora County Police Office conducted criminal investigations on three cases in 2008, 2010 and 2011. The daily Bjelovarski list and the weekly Bjelovarac were investigated. ${ }^{9}$ Following the investigation, written documentation for all three cases was forwarded to the local District Office of the Attorney General, in order to obtain an official government opinion on the cases.

In the analyzed period, the Šibenik-Knin County Police Office conducted one investigation in which it filed a criminal report to the local District Office of the Attorney General against two individuals suspected of committing a

\footnotetext{
8 Data was collected based on a right-to-information request, from the Police Directorate (Office of the Police Chief) of the Ministry of Internal Affairs of the Republic of Croatia, on April 15, 2013. No. 511-01-43-152-21-1/2013 23.

9 In 2008 a criminal investigation was conducted due to the publishing of a newspaper article in the daily Bjelovarski list, which on its cover page published a photograph and the first and last name of a boy involved in an accident. In 2010 the weekly Bjelovarac was investigated for publishing an article with the first and last names of minors who abused their underage peer. In 2011 the same weekly was investigated for an article about the abuse of an underage girl.
} 
crime under Article 304, paragraph $1^{10}$ of the Criminal Code (110/97), after the journalist of a daily newspaper published an article containing personal information about an underage girl who was a victim of sexual abuse.

\section{Office of the Attorney General of the Republic of Croatia}

From 2008 until 2012 nine criminal reports were filed to the Office of the Attorney General of the Republic of Croatia for suspicions that the crime of violating the confidentiality of legal proceedings was committed, by revealing information about the course of the proceedings against underage citizens, or information about a court decision without its permission ${ }^{11}$. Eight reports were dismissed, whereas in one case the local Office of the Attorney General issued charges together with a criminal warrant. The proceeding is currently underway in a district court.

\section{Self-regulating institutions}

\section{Croatian Journalists' Association Board of Honor}

The central mission of the Croatian Journalists' Association Board of Honor is to "uphold the dignity, honor and promote ethics and responsibility of the journalist profession" (Article 1 of the Regulations for the Operation of the Board of Honor). In its annual reports, the Board of Honor regularly issues warnings about frequent violations of children's rights in the media. The Board of Honor issued five warnings, 40 condemnations and 21 very serious condemnations to journalists and editors for violations of children's rights, in the period analyzed. ${ }^{12}$

\footnotetext{
${ }^{10}$ Article 304 (1): Whoever leads the witness or court expert to give false testimony in a court or during an administrative proceeding, a proceeding before a public notary, or a disciplinary proceeding - by force, threat, or by some other means of coercion, or by the promise of a gift or any other benefit - shall be punished by incarceration from six months to five years. Criminal Code, 110/97.

${ }^{11}$ Data was collected based on a right-to-information request, from the Office of the Attorney General of the Republic of Croatia, on April 22, 2013. No. PPI-DO-9/13.

${ }^{12}$ Presenting a great challenge to this study was the inconsistency between the statistical data from the Board of Honor annual reports and the data contained in individual decisions of the Board of Honor, available on the web pages of the Croatian Journalists' Association. Board of Honor president Trpimir Matasović issued the following explanation regarding this inconsistency: “(1) Annual reports are provided to the Assembly of the Croatian Journalists' Association before the end of the current calendar year, so they do not contain data about decisions that may have been reached in the period between the holding of the Assembly and the end of the calendar year - such data is usually
} 
Table 2: Actions taken by the Croatian Journalists' Association Board of Honor in response to children's rights violations in the media ${ }^{13}$

\begin{tabular}{|c|c|c|c|c|}
\hline Year & $\begin{array}{c}\text { No action } \\
\text { taken }\end{array}$ & $\begin{array}{c}\text { Warning / } \\
\text { advice }\end{array}$ & Condemnation & $\begin{array}{c}\text { Very serious } \\
\text { Condemnation }\end{array}$ \\
\hline 2012 & 4 & 2 & 4 & 4 \\
\hline 2011 & 2 & 2 & 9 & 4 \\
\hline 2010 & 2 & 1 & 14 & 4 \\
\hline 2009 & 3 & 0 & 5 & 6 \\
\hline 2008 & 2 & 0 & 8 & 3 \\
\hline
\end{tabular}

In 2012 the Board of Honor deliberated eight cases of children's rights violations guaranteed by the Code of Honor and some of these cases included a greater number of media outlets. Most of the reports were filed to the Board of Honor by the parents of children whose rights were violated in the media. Based on the reports, the Board of Honor issued two warnings, four condemnations and four very serious condemnations, while in four cases the Board

included in the report of the following year. (2) Much of the subject matter includes reports filed and/or decisions taken against a greater number of individual journalists and/or media - hence, the data on the number of reports and decisions, on the one hand, differs from the data on the measures issued (or unissued) against individual journalists, on the other. (3) Data from annual reports on the type of Code of Honor violation is usually divided into a number of general categories, meaning that individual cases commonly contain elements of more than one type of Code violation - hence, this portion of the statistics must also be viewed generally". Based on this advice, this study presents results that are derived from individual decisions of the Board of Honor, available on the web pages of the Croatian Journalists' Association.

${ }^{13}$ All of the data listed in the table was collected based on the decisions of the Croatian Journalists' Association Board of Honor and published on the official web pages of the Croatian Journalists' Association. The table does not include decisions for eight cases because from the conclusions of the Board of Honor it is not clear, for instance, how many condemnations were issued in some cases. One such conclusion was reached at the $3^{\text {rd }}$ Session of the Board of Honor held on February 29, 2008. Since the decision, which is listed on the web pages of the Croatian Journalists' Association, does not contain information about who the authors of these texts were, and given that the texts are no longer available on the internet, it is impossible to know how many condemnations were issued. It is, therefore, proposed that the Croatian Journalists' Association creates a public database of cases that it deliberated and for which it formulated decisions, particularly if it issued condemnations. The second obstacle we faced in the study dealt with unclear conclusions reached by the Board of Honor. Specifically, in certain cases it was not clear whether the Board issued warnings to journalists/editors or if it decided that no violation of the Code of Honor occurred. For instance, at its 24th Session held on April 30, 2010, the Board announced its decision in response to a request filed by the ombudsman for persons with disabilities, due to an article about a child involved in an accident in the daily 24 sata. The Board of Honor concluded that "no measures are to be taken against the editorial board, because it apologized immediately after realizing its mistake; however, the Board warns that such things should by no means ever occur". 
decided that no violations of the Code occurred. That year the Board of Honor (2012) issued the greatest number of very serious condemnations for inappropriate media reporting on children, in relation to other rights guaranteed by the Code. The findings of this study point to the fact that the greatest number of very serious condemnations was directed towards editors-in-chief, not journalists, which echoes the position of the Board of Honor that the greatest responsibility rests on the shoulders of the editors, not the journalists. One such conclusion was reached at the $7^{\text {th }}$ Session of the Board of Honor held on September 18, 2012..$^{14}$

In 2011 the Board of Honor deliberated 11 cases of alleged children's rights violations in the media, on the basis of which it issued two warnings/proposals, 13 condemnations, four very serious condemnations and in two cases concluding that there was no violation of the Code of Honor. ${ }^{15}$ As it mentions in its annual report, the Board of Honor (2011) has not only responded to cases of direct uncovering of children's identities, but also in instances when the identities were revealed indirectly "through detailed descriptions of places and circumstances, or by other details that indirectly revealed to the reader who the child was". In cases in which it was clear that the journalist wanted to protect the identity of the minor, but nevertheless provided information that could lead to the minor's identity being revealed, the Board of Honor (2011) issued warnings to journalists about the inappropriate nature of such texts. The greatest number of children's rights violation reports - altogether seven - was received

\footnotetext{
${ }^{14}$ Very serious condemnations were issued to the editors of the dailies Jutarnji list and Slobodna Dalmacija, on the basis of the request made by the Ombudsman for Children. The ombudsman for children warned that "information about the family, the photograph of the father published in Slobodna Dalmacija and Jutarnji list and, particularly, the diagnosis of the disease afflicting the girls, as well as other details from their private lives, reveals the identity of the sexual abuse victim - an underage girl, as well as the identity of her younger sister who witnessed this act. (...) The Code explicitly forbids the uncovering of the identity of a child who is a victim of sexual abuse, and this assumes that the identity of the perpetrator must also not be revealed if it would lead to the indirect revelation of the victim's identity". In its explanation, the Board of Honor states that no measure has been taken against journalist Dinko Borozan "because in the article, which was published in Podravski list, he did not reveal any information that could lead to uncovering the identity of the victim. However, the Code was seriously violated by the chief editors of Slobodna Dalmacija and Jutarnji list, who published a photograph of the father, poorly disguised by a black marking across his eyes, along with a row of other text details that unmistakably point to the identity of the perpetrator and, as a result, the identity of the underage sexual abuse victim. Due to the fact that there are cooperation agreements between the three newspapers, Slobodna Dalmacija and Jutarnji list carried the same article published in Podravski list, insisting that the journalist, in spite of his objections, provides them with a photograph of the father and with additional details in the text". Source: http://www.hnd.hr/hr/Zakljucci7sjednice2012/show/66194/. (Logged on web page on April 15, 2013)

${ }^{15}$ Decisions made by the Board of Honor regarding two cases were not included in the statistics because they were not completely clear, as described in note no. 13 .
} 
from the Ombudsman for Children. In other cases, it was motivated citizens and institutions that filed reports, such as the Ministry of Internal Affairs and schools.

In 2010 the Board of Honor issued, during the analyzed period, the greatest number of condemnations for children's rights violations in the media - altogether 14. It issued four very serious condemnations, one warning/proposal and in two cases it concluded that there was no violation of the Code of Honor. ${ }^{16}$ Of the 10 reports received, nine were filed by the Ombudsman for Children, echoing a great lack of interest among citizens to seek the opinion of relevant public institutions at their own initiative, upon noticing children's rights violations in the media.

In 2009 and 2010 the Ombudsman for Children filed the most reports, as well. Of the seven reports in 2009, the Ombudsman filed four. The Board of Honor issued six very serious condemnations and seven condemnations for violations of children's rights, concluding in three cases that there was no violation of the Code of Honor..$^{17}$ Of the 10 reports of children's rights violations being deliberated by the Board of Honor in 2008, the Ombudsman for Children filed seven. The Board of Honor issued condemnations in eight cases, very serious condemnations in three cases, and in two cases it concluded that no violations of the Code of Honor occurred ${ }^{18}$.

\section{Croatian Media Council}

In 2011 a self-regulating body was established in Croatia - the Croatian Media Council - with responsibility for monitoring and sanctioning violators of ethical norms in journalism. ${ }^{19}$ However, since its establishment until today, it has not yielded any discernible results. It does not publish any reports on their web site.

\footnotetext{
${ }^{16}$ Decisions made by the Board of Honor regarding four cases were not included in the statistics because they were not completely clear, as described in note no. 13 .

${ }^{17}$ A decision made by the Board of Honor regarding one case was not included in the statistics because it was not completely clear, as described in note no. 13 .

18 Ibid.

${ }^{19}$ Its founder was the Association of the Croatian Media Council, with the support of the Ministry of Culture, Electronic Media Council, Croatian Chamber of Economy and the Konrad Adenauer Foundation from Germany.
} 


\section{Ombudsman for Children ${ }^{20}$}

According to the Act, the duty of the Ombudsman is, among other things, to monitor the fulfillment of obligations of the Republic of Croatia, stemming from the Convention on the Rights of the Child and other international documents having to do with the protection of children's rights and interests; to monitor the implementation of all legal regulations dealing with the protection of children's rights and interests (Article 6 of the Ombudsman for Children Act, 96/03). From this it can also be deduced that it is the duty of the ombudsman to monitor media reporting on children and the respect of their rights. Although lacking the authority to sanction anyone for violating children's rights in the media and having permission only to issue warnings and offer advice, the Ombudsman regularly monitors media content about children and informs relevant institutions ${ }^{21}$ about cases of children's rights violations. One of the findings of this study is that these institutions most commonly respond to children's rights violations in the media only after the denunciation of the Ombudsman for Children, while cases of independent responses of these institutions, at their own initiative, are very uncommon.

Table 3: Reports filed by the Ombudsman for Children to relevant institutions about violations of children's rights in the media (2008 - 2012)

\begin{tabular}{|c|c|c|c|c|c|}
\hline Year & $\begin{array}{c}\text { Reports } \\
\text { received }\end{array}$ & $\begin{array}{c}\text { Warnings of the } \\
\text { ombudsman sent to } \\
\text { journalists, editors and } \\
\text { publishers/broadcasters }\end{array}$ & $\begin{array}{c}\text { Reports to } \\
\text { Croatian } \\
\text { Journalists' } \\
\text { Association }\end{array}$ & $\begin{array}{c}\text { Reports to } \\
\text { the Elec- } \\
\text { tronic Me- } \\
\text { dia Council }\end{array}$ & $\begin{array}{c}\text { Reports } \\
\text { to the } \\
\text { Attorney } \\
\text { General }\end{array}$ \\
\hline 2012 & 21 & 5 & 3 & 1 & 3 \\
\hline 2011 & 29 & 21 & 12 & 5 & 7 \\
\hline 2010 & 40 & 15 & 12 & 3 & 6 \\
\hline 2009 & 13 & 6 & 6 & 0 & 1 \\
\hline 2008 & $\begin{array}{c}28+10 \\
\text { notices }\end{array}$ & 11 & 15 & 0 & 2 \\
\hline
\end{tabular}

\footnotetext{
${ }^{20}$ The Office of the Ombudsman for Children of the Republic of Croatia was established in 2003, in line with the Ombudsman for Children Act (96/03).

${ }^{21}$ I.e. the Electronic Media Council, Attorney General of the Republic of Croatia and the Croatian Journalists' Association Board of Honor.
} 
From 2008 until 2012 the Ombudsman for Children filed nine reports about children's rights violations to the Electronic Media Council (in further text: Council), the body responsible for monitoring electronic media. ${ }^{22}$ The greatest number of cases, which prompted the Ombudsman for Children to respond, occurred in 2011. Five reports were filed to the Council for violations of children's rights: one for Radio Petrinja, novilist.hr and jutarnji.hr, respectively, and two for the internet portal index.hr. The Council issued warnings or condemnations in three of these cases. In 2010 the Council was informed of three cases of violations of children's privacy. The first two involved Nova TV and $R T L$, while the third involved a number of electronic media outlets, which reported about an artist suspected of sexually abusing his son. Namely, the outlets indirectly revealed the identity of the abused child while providing information about the father. The Council responded in two of these cases.

The Ombudsman for Children is also responsible for informing the Attorney General of the Republic of Croatia about serious violations of children's privacy in the media, particularly when it comes to sexual abuse or uncovering the identity of children who are perpetrators of criminal offenses and other violations. Nineteen such cases were reported in the analyzed period and they most commonly dealt with the uncovering of identities of children who were victims of sexual abuse. In 2008 the Ombudsman reported two such cases, although they involved a greater number of media outlets - altogether nine ${ }^{23}$. In 2009 the Ombudsman informed the Attorney General of only one children's rights violation case ${ }^{24}$. In 2010 six cases were reported to the Attorney General: two reports involved the daily Jutarnji list and the others involved Slobodna Dalmacija, Glas Slavonije, Glas Istre and HINA. One year later reports were filed against seven media outlets for children's rights violations: Radio Petrinja, index.hr (two re-

\footnotetext{
${ }^{22}$ According to the Office of the Ombudsman for Children, reports to the Electronic Media Council for children's rights violations in the electronic media started to be filed systematically since 2010, when the protection of privacy was more clearly defined in the Electronic Media Act and in the Regulations for the Protection of Juveniles. However, most of the reports filed to the Council are in regard to inappropriate media content for children.

${ }^{23}$ In the first case, eight media outlets (Narodni list Zadar, Nova TV, index.hr, javno.hr, Jutarnji list, nacional.hr, TotalPortal, net.hr) revealed the identity of the father of the sexual abuse victim, suspected of abusing his daughter, which indirectly led to the uncovering of the identity of the abused girl. In the second case, a report was filed against the local newspaper Bjelovarski list after it published on its cover page photographs of a child whose face was deformed by severe burns, after attempt of suicide, as well as for revealing the child's first and last name with other personal data.

${ }^{24}$ It involved an article in the daily newspaper 24 sata, which falsely informed about the death of a young girl, also including photographs of the girl, and which was published while the young girl was undergoing therapy and even happened to see the article herself.
} 
ports), Jutarnji list, Vecernji list, Slobodna Dalmacija and Novi list. In 2012 the reports involved Slobodna Dalmacija and two reports centered on Jutarnji list for its revelation of the identity of a sexual abuse victim.

The Ombudsman also reports cases of children's rights violations in the media to a self-regulating body, the Croatian Journalists' Association Board of Honor (in further text: Board of Honor). The most reports, altogether 48, were filed to this association in the past five years. The Board of Honor does not perform independent monitoring of the media. Instead, it responds to particular actions and evaluates whether they were ethical and in line with regulations of the Code of Honor, but only after receiving complaints about possible Code violations. This study found that it is the Ombudsman for Children who most commonly files reports to the Board of Honor about cases of children's rights being violated in the media. Few reports were filed by the citizens themselves. In almost all cases, the Board of Honor issued warnings, condemnations, or very serious condemnations to journalists and editors of the media outlets in question. In 2012 the Ombudsman for Children filed three reports to the Board of Honor, on the basis of which the Board issued four very serious condemnations to editors-in-chief and three less serious condemnations to the journalists involved. In 2011 there were 12 cases reported. The Board of Honor issued condemnations to journalists and editors on the basis of 10 reports, in one instance issuing a warning and in another taking the position that there was no violation of the Code of Honor. The same number of reports was filed in 2010. In 2009 the Ombudsman for Children filed six reports to the Board of Honor for children's rights violations in the media, which responded to all of them by issuing condemnations and very serious condemnations to journalists and, in most cases, to editors as well. In the analyzed period, the greatest number of reports was filed in 2008 - altogether 15 - following which the Board of Honor issued condemnations and very serious condemnations to journalists and editors in 13 cases.

The greatest number of reports filed by the Ombudsman for Children to the Board of Honor - altogether 37 - centered on print media. One can explain this by the fact that the Ombudsman for Children does not perform systematic monitoring of the media, due to a lack of funds, and therefore its focus is mainly on print media and, in particular, daily newspapers. Six reports were filed concerning web portals, three centered on television stations and one of each was filed in regard to a radio station and a news agency, respectively. 
Table 4: Reports filed by the Ombudsman for Children to the Croatian Journalists' Association Board of Honor according to media type (2008 - 2012)

\begin{tabular}{|c|c|c|c|c|c|}
\hline $\begin{array}{c}\text { Print } \\
\text { media }\end{array}$ & Radio & Television & Web portals & News agencies & Total \\
\hline 37 & 1 & 3 & 6 & 1 & 48 \\
\hline
\end{tabular}

The Ombudsman for Children does not only inform relevant regulatory and self-regulating bodies about violations of children's rights to privacy, dignity, reputation and honor in the media, but also regularly issues warnings to journalists, editors-in-chief and publishers/broadcasters to draw to their attention omissions in the reporting process and to warn of children's rights violations in the media and of the consequences that follow. In the past five years such warnings were issued on 58 occasions. ${ }^{25}$

\section{Conclusion}

The responsibility of regulation and self-regulation institutions has proven to be a serious obstacle, as it does not exist in the Croatia media system. Without this responsibility, it is not possible to ensure the full protection and promotion of children's identities. Although obliged to respond by sanctioning, either from a legal or moral perspective, it is uncommon for institutions such as the Electronic Media Council, the Ministry of Internal Affairs, the Office of the Attorney General, the Croatian Journalists' Association Board of Honor and the Croatian Media Council to issue fines for children's rights violations in the media. Indeed, instances of children's privacy rights violations in the media are much more frequent than the legal processing of such cases. This can best be observed by using the example from 2010, when the annual analysis of

\footnotetext{
25 The greatest number of warnings was issued to media outlets in 2011 - altogether 21. In 200811 warnings were issued, in 2009 six were issued, in 201015 were issued and in 2012 five were issued. The greatest number of warnings was issued to print media - a total of 38 - most of them being addressed to journalists and newspaper editors, once again as a result of the aforementioned lack of systematic media monitoring. In nine instances the warnings were issued to journalists and editors of national television stations (HTV, NOVA TV, RTL) and an equal number of warnings were addressed to web portals. Only one warning in the past five years was issued to a radio station and a news agency, respectively. Although these findings cannot draw us to the conclusion that children's rights are more often violated in the print media, as opposed to electronic media and new media - due to the already mentioned lack of systematic media monitoring - it is noticeable, for instance, that some print media violate children's privacy more often than others. While 10 warnings were issued to the Jutarnji list daily, eight to the Slobodna Dalmacija daily and six to the 24 sata daily, the newspapers Novi list and Glas Istre, which enjoy a reputation as more serious newspapers, were issued only one warning each in the past five years.
} 
seven Croatian daily newspapers showed that there were 602 articles in which the identities of children were revealed, as well as 197 articles that included photographs revealing children's identities, although they should clearly have been protected because the cases involved children who were victims, witnesses or perpetrators of crimes, or whose family members participated in criminal activities.

By monitoring the work of the relevant institutions, the extent to which children's rights are being violated in the media is not apparent, since - as the findings of this study confirm - significantly less cases were processed in the analyzed period, as opposed to those that actually occurred. Of all the analyzed institutions, the Office of the Ombudsman for Children has proven as the most efficient in the defense of children's rights, and through its actions and reports filed to other relevant institutions, in spite of lacking the authority to legally process cases, the Ombudsman affirmed its central role in the protection of children's rights in the media. In contrast to regulatory bodies, which have in the analyzed period responded to only a few cases, the Croatian Journalists' Association Board of Honor issued warnings and condemnations on a yearly basis for children's rights violations, most commonly following the submission of reports from the Ombudsman for Children and some motivated citizens.

However, as we have shown by an analysis using the example of Croatia, legal regulations are often not implemented in practice, or the path to their implementation is arduous, leading many parents and children to give up on the realization of their rights. Likewise, relevant bodies responsible for the application and implementation of ethical and legal norms tend to approach the issue of children's rights violations in the media with varying levels of intensity and engagement, as the example from 2010 shows.

In Croatia the Electronic Media Council is in charge of the monitoring and regulation of electronic media. But there is no council or institution with similiar tasks or obligations responsible for print media. Consequently, we propose the following: when it comes to the issue of children's rights violations it is necessary to define, in a timely fashion, the authorities and obligations of an ad hoc body, or to transfer authorities to a body that already exists. In this way the gap in the regulation of print and electronic media, in matters of protection of children's privacy rights, would be bridged. This is a fundamental prerequisite to systematic monitoring of the media, particularly when it comes to reporting about children. 
Apart from the systematic monitoring of the media, it is of key importance that the institutions responsible for implementing on the own initiative legal and self-regulation acts indeed do process cases of children's rights violations, in line with their authorities, but not only at the initiative of the Ombudsman for Children or motivated citizens and institutions. Improved coordination and better cooperation among the relevant institutions is needed as well, in order to adequately warn of children's rights violations and to sanction perpetrators in a timely fashion, as well as to prevent such acts or those of a similar nature from occurring in the future.

Finally, we would like to highlight the urgent need for a large spectar of journalists' in-service educational programs. Ten years ago through activities of ICEJ (International Center for Education of Journalists, established by CJA), numerous seminars, workshops and conferences for journalists were organized, at which they could learn and practice reporting on children's rights. However, at the present time and outside academic society, it is difficult to find similar specialized courses for journalists covering children's rights.

While journalists' associations have failed in providing special courses, academic socitey has founded new studies, programs and courses on several educational levels. The University of Zagreb has through its Centre for Croatian Studies and Faculty of Political Science initiated courses on Children and Media and Media and Rights of Children. Since these institutions still educate large numbers of journalists and communicologists, we believe this will have a strong impact in the long term. Simultaneously, the University of Zagreb Faculty of Law has founded a special postgraduate interdisciplinary study program on Children's Rights. Academic institutions will play a significant role in raising awareness of the public about the importance of protection of children's rights in the media, but journalists and other media staff should also invest great efforts not only by following ethical codes and regulations but also by providing examples of good practices.

While the media have undergone a significant transformation in the past decade, the need for professional reporting about children and their rights most definitely has not. The Croatian media system lacks both more efficient media regulation and self-regulation. Children, as the most helpless members of society who are not capable of protecting their rights on their own, deserve to have a unique system in place for the protection of all of their rights, including their rights in the media. 


\section{References}

Aroldi, P. (2004). Television and Protection of Minors in Some European Countries. A Comparative Study. In Von Feilitzen, C. \& Carlsson, U. (eds.), Promote or Protect? Perspectives on Media Literacy and Media Regulations. Nordicom: Goteborg University, pp. 179-196.

Ciboci, L., Jakopović, H., Opačak, S., Raguž, A. \& Skelin, P. (2011). Djeca u dnevnim novinama. (Children in Daily Newspapers) In Ciboci, L., Kanižaj, I., Labaš, D., Djeca medija. Od marginalizacije do senzacije. (Children of the Media. From Marginalization to Sensationalism.) Zagreb: Matica hrvatska (Croatian Heritage Association), pp.103-166.

Frau-Meigs, D. (2004). Media Regulation, Self-Regulation and Education. Debunking Some Myths and Retooling Some Working Paradigms. In Von Feilitzen, C. \& Carlsson, U. (eds.), Promote or Protect? Perspectives on Media Literacy and Media Regulations. Nordicom: Goteborg University, pp. 23-40. Grisold, A. (1996). Press Concentration and Media Policy in Small Countries: Austria and Ireland Compared, European Journal of Communication, 11(4): 485-509.

Jones, L.M., Finkelhor, D. \& Beckwith, J. (2010). Protecting Victims' Identities in Press Coverage of Child Victimization. Journalism, 1 (3), 347-367.

Karppinen, K. (2006). Media Diversity and the Politics of Criteria: Diversity Assessment and Technocratisation of European Media Policy. Nordicom Review, 27(2): 53-68.

Kilpatrick, D. G., Edmunds, C. \& Seymour, A. (1992). Rape in America: A report to the Nation. Charleston: National Victim Center \& Crime Victims Research and Treatment Center, Medical University of South Carolina.

Lunt, P. \& Livingstone, S. (2012). Media Regulation. Governence and the Interests of Citizens and Consumers. Sage: London, Thousand Oaks, New Delhi, Singapore.

McQuail, D. (2010). McQuail's Mass Communication Theory. Sage: London, Thousand Oaks, New Delhi, Singapore.

Palzer, C. \& Scheuer, A. (2004). Self-Regulation, Co-Regulation \& Public Regulation. In Von Feilitzen, C. \& Carlsson, U. (eds.), Promote or Protect? 
Perspectives on Media Literacy and Media Regulations. Nordicom: Goteborg University, pp. 165-178.

Puddephatt, A. (2011). The Importance of Self-Regulation of the Media in Upholding Freedom of Expression, UNESCO, CI Debates, No. 9.

Puppis, M. (2009). Media Regulation in Small States. International Communication Gazette, 71(1-2), 7-17.

Rivoltella, P. C. (2006). A European Research Project: The Appropriation of New Media by Youth. Accessed 25.04.2013. URL: http://www.mediappro.org/ publications/finalreport.pdf.

Rivoltella, P. C. (2012). Beyond Digital Natives: European Research on Media education; Challenges of Technology and Pedagogical Issues. Educational Technology, 4(2) 25-29.

Sousa, H., Trützschler, W., Fidalgo, J. \& Lameiras, M. (2013). Introduction. In Sousa, H., Trützschler, W., Fidalgo, J., Lameiras, M. (eds.), Media Regulators in Europe: A Cross-Country Comparative Analysis. Braga: CECS - Communication and Society Research Centre, University of Minho, pp. 5-10.

Zlatev, O. (2011). Media Accountability Systems (MAS) and Their Applications in South East Europe and Turkey. Professional Journalism and Self-Regulation. New Media, Old Dilemmas in South East Europe and Turkey. Paris: UNESCO, pp. 17-39.

\section{Other sources}

The Constitution of the Republic of Croatia, Official Gazette 85/10 The Media Act, Official Gazette 59/04, 84/11

The Electronic Media Act, Official Gazette 153/09, 84/11, 94/13

The Croatian Radio-Television Act, Offcial Gazette 137/10, 76/12

The Regulations for the Protection of Juveniles, Official Gazette 60/10

The Criminal Code, Official Gazette 110/97, 125/11, 144/12

The Amendments to the Criminal Code, Official Gazette 71/06

The Juvenile Courts Act, Official Gazette 84/11, 143/12

The Criminal Offenses Act, Official Gazette 107/07 
Code of Honor for Croatian Journalists

Croatian Journalists' Association Board of Honor Annual reports and statistics http://www.hnd.hr/hr/ZakljucciNovinarskogvijecacasti/. (Logged on web page on February 17, 2013)

Electronic Media Council (2012) - Annual report for 2012.

http:/www.e-mediji.hr/files/repozitorij/KRSENJE_ZEM-a_2012.pdf. (Logged on web page on February 17, 2013)

Electronic Media Council (2011) - Annual report for 2011.

http://www.e-mediji.hr/files/repozitorij/2011_povrede_ZEM-a.pdf . (Logged on web page on February 17, 2013)

Electronic Media Council (2010) - Annual report for 2010.

http://www.e-mediji.hr/files/repozitorij/2010_povrede_ZEM-a.pdf. (Logged on web page on February 17, 2013)

Electronic Media Council (2009) - Annual report for 2009.

http://www.e-mediji.hr/files/repozitorij/2009_povrede_ZEM-a.pdf. (Logged on web page on February 17, 2013)

Electronic Media Council (2008) - Annual report for 2008.

http://www.e-mediji.hr/files/izvjesca/IZVJESCE_ELEKTRONICKI_ MEDIJI_151.pdf. (Logged on web page on February 17, 2013) 